\title{
Improving Students’ Public Speaking Skill through Instagram
}

\author{
Difiani Apriyanti, Syofiani, Syahrul Ramadhan, Mukhaiyar \\ Politeknik Negeri Padang, Universitas Bung Hatta, Universitas Negeri Padang, Universitas Negeri Padang \\ difi_apriyanti@yahoo.com,
}

\begin{abstract}
Public speaking in English is a needed skill for leaders and staffs in any offices and companies in Indonesia. In this globalization era, skill to communicate effectively and efficiently in English during a meeting or a teleconference with foreigners is needed, such as for company product promotion, or during building cooperation. Therefore, public speaking course is occupied by employees since they have an important role for the company development. Since the needs of this skill is high, universities in Indonesia have started providing course of Public Speaking in English. One of them is English Department in Politeknik Negeri Padang. In teaching public speaking, the teacher must teach them to overcome their fear, show their confident, perform perfectly, and used good English. Unfortunately, performing in their reguler class, infront of their classmates and lecturers did not build any of them. An action was taken by asking the students to upload their performance in their personal instagram application. Instagram was chosen since the application provides a variety of video that get shared to instagram daily. View, comment, and like from the viewers would be the important part of building the character of the students to be like a professional public speaker. From several times presenting their public speaking activities in instagram, Categories 'state in purpose' 'organize the content', and 'summarize the main idea' are in level 5 (high) which means highest improvement. Category 'speak clearly with appropriate vocabulary and information', 'uses tone, speed, and volume as tool', and 'appears comfortable with audiences' in level 4 which is between high and average. Meanwhile, it still can be seen that students need more on English knowledge such their numbers of vocabularies and English structure. In conclusion, instagram application can be one of the media for improving students' public speaking skill especially in building the character of a public speaker.
\end{abstract}

Keywords-public speaking; instagram; teaching

\section{INTRODUCTION}

In recent years, Indonesian companies and offices have considered the need of acquiring public speaking skill for their staffs. They need them to communicate effectively and efficiently for supporting their promotion and cooperation. Globalization era has forced and brought them to widen their projects not only in Indonesia, but also spread out to other countries. By having this international works, obviously they need staffs who can speak English well.

Companies that are developed, start sending their staffs to public speaking courses. They give this facility to them since public speaking is not a skill that can be learnt alone at home, or by reading it from books. It is a skill which can be acquired if the person has experienced on it. He must show his confident and be attractive, and in the same time controlling his fear and anxiety during performance.

Actually, public speaking fear is the most popular issue in public speaking. Several reseraches had been done, such as conducting awareness training in overcoming public speaking fear (Spieler 2015), and doing video self model to treat public speaking anxiety are some of them (Kruger 2013). However, these researches did not tool or media which are interested and comfort by the speakers in order to give their best performance.

In this research, instagram which is popular and enthusiast by most social media users was used to support public speaking performance. English Department students of Politeknik Negeri Padang who was taking Public Speaking course did not have improvement on their performance. The audiences which were their classmate and the room which was their reguler classroom cannot motivate them in giving the best performance. They did not feel the challenge being in the situation, condition, and atmosphere that are common for them.

Since instagram is one of the social media that facilitate video in good quality and also instagram can be watched by many people, and also being commented, the research used viewers comments or like to get students"e motivation. The students recorded their performance and uploaded the video to their instagram. Therefore, this research describes the influence of conducting public speaking in instagram toward students" public speaking performance

\section{Public Speaking}

A public speaker needs to pay attention on their voice such as tone, speed, accent, pitch, and clarity (Lamerton 2001), as well on the body movement during performance (O'Hair, Rubenstein, and Stewart 2010). They also must be able to enggage with their audiences and be aware if the audiences lost their interest (O'Hair, Rubenstein, and Stewart 2010). Therefore, candidate of public speaker usually face anxiety which is called as public speaking. Actually, the nervous feeling during public speaking is normal (Lucas 2009). This fear also occurs on students who are are joining public speaking course. This feeling shows up because lack of involvement in speaking to groups of people (Marinho et al. 2017). Public speaking fear usually happens to college students from rest to the beginning of the presentation, during 
the first minutes of the presentation, and during the last minutes of the presentation (Behnke, Ralph R. \& Sawyer 2004). Therefore, many kinds of approaches and training, and even courses that have been conducted to overcome the fear (Hancock et al. 2010), such as changing the atmos 'fear ${ }^{\text {ee }}$ in the public speaking classroom. They suggest to create in the class respecting cultural differences, avoiding instructor bias, using classtime for practice, and providing an encouraging classroom (Stewart and Tassie 2011). While attempting to evaluate the effect of video self modelling (VSM) on public speaking anxiety has also been done. VSM is a form of social learning where the individual serves as his own model for vicarious learning. The treating speech anxiety include standing amount of time at the podium with no audience, with an audience, and giving progressively longer speeches until no longer anxious in delivering a speech. of the person (Kruger 2013). Then conducted training that makes a person aware of his anxiety was also carried out (Spieler 2015).

Therefore, it can be said that a public speaker is a challenge skill which means the pers on must show his confident, being attractive, controlling the events, and in the same time covering his fear and anxiety which usually appear during performance. To teach students being a real public speaker means being the students of public speaker which is full of fear and anxiety but must show an attractive performance.

\section{Instagram}

Smart phone and portable devices have been part of people life . The devices are usually equipped with internet and socal media applications such as instagram, whatsApp, Youtube, Facebook, Wikipedia, and many others. These social media tend to be used for socializing and communication with family and friends (Kolokytha, Loutrouki, and Florou 2015), and also for uploading pictures and videos. Actually, in instagram, there are a variety of video that get shared to instagram daily. The videos are stop-motion videos, talent video, How-to videos, Personal messages, and Time-lapse videos (Herman 2014). Actually the specification that exist in instagram can be used for education site,

Instagram users can display their talent and skill in talent videos and give tips and advice on how to do something well by sharin $g$ it in How-to videos. Making a big announcement also can done in video of personal messages. These videos can be seen by other people, and also can be commented. People can leave a comment on a post by click on the little comment bubble beneath the post and previous comments. This will open up a comment box where message is typed, and by sending click "send" to upload the comment. Comments also can be gotten when the videos are shared to other sites like facebook or twitters.

Social media is one approaching in teaching. Teachers who plan to use social media need training in order to make the practice in the class more functionable (Alabdulkareem 2015) Teacher can evaluate the use of it, and also teachers ${ }^{\text {ce }}$ abilities in use available properties of the tool can increase, also to make class fun. Sheldon (2015) said that Actually,using learning by using social media in class is fun, but unfortunately not so many teachers doing it, and there are some teachers who are using it inappropriately, therefore the students suggest them to be more interactive and thoughtful (Sheldon 2015). Users often ignore the used of Social Media Network as a learning tool with a suitable guidance (Kolokytha, Loutrouki, and Florou 2015).

Therefore, it can be said concluded that instagram as a social media which provides a variety of videos can used for education side if it is used with a suitable guidance and experienced teacher.

\section{METHODS}

This research was descriptive-qualitative research. It pictures students ${ }^{\text {ee }}$ public speaking performances which were upload in their instagram. The performances were described as the way things are without any manipulation (L.R.Gay, Millis, and Airasian 2012). The data was gotten in public speaking class in English Department of Politeknik Negeri Padang. The sample of the research was taken from students of semester four periode 2017-2018. The numbers of the samples were 25 students who came from class $2 \mathrm{~A}$. In getting the data, the researcher had internet connection to sign in to instagram application and watched the students ${ }^{\text {ee }}$ videos. The data which were the students ${ }^{\text {ee }}$ performance was analyzed by using public speaking quick references card which also show the level. Level 5 means high, 3 means average, 1 means low. A score of 4 or 2 are in the middle. This card caused the researcher to be consistent in picturing the data.

\section{FINDING AND DISCUSSION}

\section{Finding}

After one semester, the students had uploaded their video to their instagram 4 times. They did the presentation or perfomance with different topics. The videos were watched and commented by the viewers. The fifth videos were the data which were analysed by the researcher by using public speaking rubric. From the analysis, the result can be seen in table. 
Table 1

\begin{tabular}{|c|c|c|c|c|c|}
\hline & \multicolumn{5}{|c|}{ Percentage Students in Level: } \\
\hline Level & 1 & 2 & 3 & 4 & 5 \\
\hline 1.States the Purpose & & & & & 100 \\
\hline 2.Organize the Content & & & & 20 & 80 \\
\hline 3.Supports Ideas & & & 80 & 20 & \\
\hline 4.Incorporatesstories and examples & & 80 & 20 & & \\
\hline 5.Summarizes the Main Idea & & & & 48 & 52 \\
\hline 6.Demonstrates awareness of listeners ${ }^{\text {ee }}$ needs & & & 100 & & \\
\hline $\begin{array}{l}\text { 7.Speaks clearly with appropriate vocabulary and } \\
\text { information }\end{array}$ & & & & 100 & \\
\hline 8.Use tone, speed, and volume as tools & & & & 100 & \\
\hline $\begin{array}{l}\text { 9.Demonstrate complexity of thought and } \\
\text { vocabularies }\end{array}$ & & & 80 & 20 & \\
\hline 10.Appears comfortable with audience & & & & 100 & \\
\hline
\end{tabular}

It can be seen that having instagram viewers watching the studentse performance had successfully put ,state in purpose $^{e e}$,organize the content ${ }^{e e}$, and ,summarize the main idea ${ }^{e e}$ in level 5. It means that most of the student got high improvement on these skills. It shows that students focused to make their viewers understand the content their presentation from beginning until the end.

Not only the content, using instagram as public media, the students show that they had tried their best on their voice, mime, and body movement to attract the viewers keep wanting to watch their performance. This can be seen from category ,speak clearly with appropriate vocabulary and information ${ }^{\text {ee }}$, uses tone, speed, and volume as tool ${ }^{\text {ee }}$, and ,appears comfortable with audiences ${ }^{\text {ee }}$ in level 4 which is between high (level 5) and average (level 3 ).

Meanwhile, it still can be seen that students need more on English knowledge such their numbers of vocabularies and English structure. Therefore, they can express their ideas, put them in a good order to be more qualified

\section{Discussion}

From the finding, it can be seen that teaching public speaking means changing the atmosphere. Students need to face and feel different every time doing their performance since it will effect their emotion and confident. Changing the atmos $^{\text {ee }}$ ear ${ }^{\text {ee }}$ in their public speaking classroom has also been carried out, and it brought a good result (Stewart and Tassie 2011).

It can be seen that students are being more motivated when they are being watched by people who are not familiar with them and situation which is not common for them. They feel like being challenge by having this new surrounding which later bring up their confident to give the best. According to the arousal theory of motivation, when a person rousal levels drop below these personalized optimal levels, he will seek some sort of stimulation to elevate them. Therefore, a student can be a professional public speaker if he/she can feel the fear of it and overcome it.

Furthermore, although there are many variety video that can be shared to instagram daily, most students prefer to choose talent video and How -to videos. They like to perform something that they are comfortable in it and sure that have known about it.

\section{SUMMARY}

In conclusion, public speaking course needs to taughy by building studentse challenge. One of the ways is done by showing their performance in social media which is watched by their friends and family. In giving the challenge, the teacher must grab students ${ }^{e e}$ attention by choosing social media application can be acessed in smartphone. As it is known, students nowdays are so fanatic with their smartphone. Beside that, the teacher must be selective in choosing the application which is suitable with the focus of the tasks. Since the task is uploading video, instagram is the best choice. Variety of video can be share to instagram daily.

In addition, it can be seen that students really want their viewers to understand their performance from the begining to the end of their presentation, therefore they try to support their performance by playing with their voice, mime, and gesture.

\section{References}

Alabdulkareem, S. A. (2015). "Exploring the Use and the Impacts of Social Media on Teaching and Learning Science in Saudi." In Exploring the Use and the Impacts of Social Media on Teaching and Learning Science in Saudi Saleh, Elsevier B.V., 213-24. http://linkinghub.elsevier.com/retrieve/pii/S1877042815030335. 
Behnke, R. R. \& Sawyer, C. R. (2004). "Public Speaking Anxiety as a Function of Sensitization and Habituation Processes." Communication Education 53, 2004(2): 164-1173.

Hancock, Adrienne B., Matthew D. Stone, Shelley B. Brundage, and Mark T. Zeigler. (2010). "Public Speaking Attitudes: Does Curriculum Make a Difference?" Journal of Voice 24(3): 302-7. http://dx.doi.org/10.1016/j.jvoice.2008.09.007.

Herman, By Jenn. 2014. "The Ultimate Beginner " S Guide To Instagram." : 35.

Kolokytha, E., S. Loutrouki, \& SVG Florou. (2015). "Social Media Networks as a Learning Tool.” In Elsevier, $287-95$. Kruger, A. (2013). "The Use of Video Self-Modeling to Treat Public Speaking Anxiety." Minnesota State University.

L.R. Gay, Geoffrey E. Millis,\& P. W. Airasian. (2012). Educational Research. 10th ed. Pearson.

Lamerton, J. (2001). Public Speaking (Everything You Need To Know). London: HarperCllins Publisher.

Lucas, Stephen E. (2009). The Art of Public Speaking. tenth Edit. ed. Erika Lake. Madison: Frank Mortimer.

Marinho, ACF., AM de Medeiros, Ana Cristina Côrtes Gama, and Letícia Caldas Teixeira. (2017). "Fear of Public Speaking: Perception of College Students and Correlates." Journal of Voice Volume 31(Issue 1): 127.e7-127.e11.

O`Hair, D., H. Rubenstein, \& R. Stewart. (2010). A Pocket Guide to Public Speaking. third edit.

Sheldon, P. (2015). Social Media. Lexinton.

Spieler, C. (2015). "Using Awareness Training to Decrease Nervous Habits in Public Speaking." University of South Florida.

Stewart, F., \& KE Tassie. (2011). "Changing the Atmos"Fear" in the Public Speaking Classroom.” International Journal of Humanities and Social Science 1(7): 9-13. 